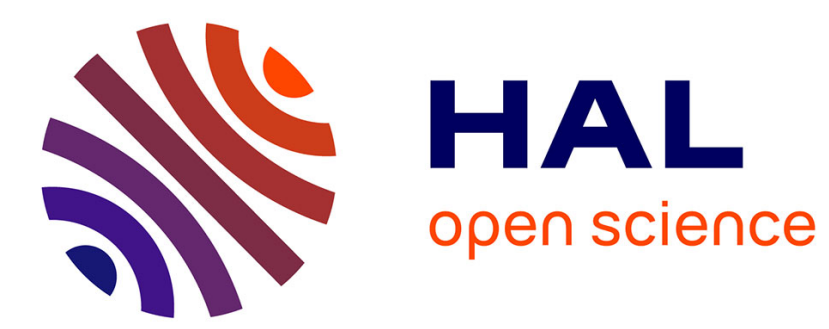

\title{
Micro-optics and Bragg gratings for DWDM sources array
}

\author{
M Thual, P. Chanclou, J Lostec, A. Laurent, H Poignant
}

\section{To cite this version:}

M Thual, P. Chanclou, J Lostec, A. Laurent, H Poignant. Micro-optics and Bragg gratings for DWDM sources array. Optics Communications, 2000, 176 (4-6), pp.393-396. 10.1016/S0030-4018(00)00536-8 . hal-02920605

\section{HAL Id: hal-02920605 https://hal.science/hal-02920605}

Submitted on 24 Aug 2020

HAL is a multi-disciplinary open access archive for the deposit and dissemination of scientific research documents, whether they are published or not. The documents may come from teaching and research institutions in France or abroad, or from public or private research centers.
L'archive ouverte pluridisciplinaire HAL, est destinée au dépôt et à la diffusion de documents scientifiques de niveau recherche, publiés ou non, émanant des établissements d'enseignement et de recherche français ou étrangers, des laboratoires publics ou privés. 


\title{
Micro-optics and Bragg Gratings for DWDM Source Array
}

\author{
M. Thual, P. Chanclou, J. Lostec, A. Laurent, *H. Poignant \\ FRANCE TELECOM, CNET, DTD/PIH, *DTD/RTO \\ 2, avenue Pierre Marzin, 22307 LANNION CEDEX \\ monique.thual@cnet.francetelecom.fr
}

\begin{abstract}
A collective process is presented to achieve a four channels fibres ribbon with long working distance micro-optics (46 $\pm 0.7 \mu \mathrm{m})$ and UV-induced Bragg Gratings. Four different external cavity single-longitudinal mode sources are obtained with this fibres ribbon in front of a Fabry Perot Laser Diode (FP/LD) at a wavelength around 1300 nm with Side Mode Supression Ratio of $44.35 \pm 1.85 \mathrm{~dB}, 3 \mathrm{~dB}$ bandwith of $76 \pm 1.7 \mathrm{pm}(13.7 \mathrm{GHz})$ and Relative Intensity Noise around $-138.6 \pm 2.8 \mathrm{~dB} / \mathrm{Hz}$. This is promising for assembling multichannel multiwavelengths emitters for Dense Wavelength Division Multiplexing (DWDM) networks.
\end{abstract}

Keywords: External cavity laser diode; Microlens array, Bragg grating

\section{Introduction}

The use of UV-written Bragg reflector in telecommunication SingleMode Fibre (SMF) to obtain single-longitudinal mode external cavity LD has already been demonstrated [1] [2] [3] [4]. These kinds of sources require highly efficient coupling and low parasitic reflections on LD and fibre [1]. Elsewhere the interest of collective and passive assembling of LD array and SMF ribbons to reduce the cost and size of emitters at the central office has been shown [5]. We have reported recently highly efficient and long working distance collective micro-optics suitable for those multichannel modules [6]. In this letter, we propose to investigate the association of both UV-writing and micro-optics fabrication technologies on fibre ribbon to achieve a multiwavelengths multichannel external cavity laser diode source (Figure 1) for DWDM applications. These micro-optics are a compromise between the coupling loss inside the cavity and tolerance to misalignment for collective assembling [6].
This device is expected to be less sensitive to temperature than Distributed Bragg Reflector laser diode due to the lower temperature dependence of the Bragg grating in silica, $15 \mathrm{pm} . \mathrm{K}^{-1}$, compared with $100 \mathrm{pm} . \mathrm{K}^{-1}$ for DBR laser diode.

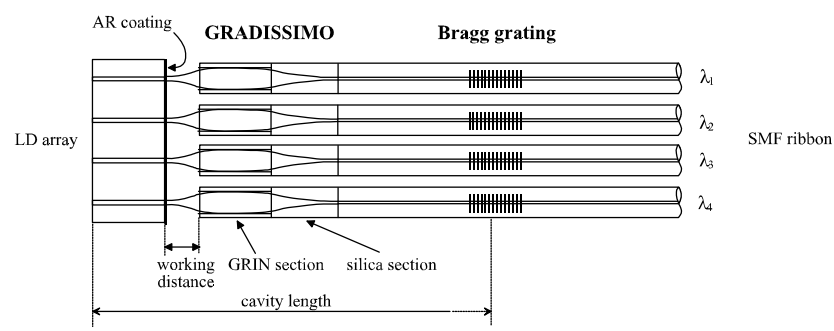

Fig. 1 Laser Diode array and SMF ribbon with micro-optics and Bragg gratings. 


\section{Fabrication process}

Bragg reflectors centred on appropriate wavelengths $\left(\lambda_{1}=1280, \lambda_{2}=1282.46, \lambda_{3}=1284.76, \lambda_{4}=1286.81 \mathrm{~nm}\right)$ were first $\mathrm{UV}$-written within each of the standard ribbon including four $250 \mu \mathrm{m}$ spaced SMF. The UV exposure was achieved using a transverse holographic arrangement (Lloyd mirror) [7] involving a frequency doubled Argon ion laser (Sabre Fred, from Coherent), operating at $\lambda_{\mathrm{P}}=244 \mathrm{~nm}$. $100 \mathrm{~mW}$ output powers were used for this experiment.

Prior to the irradiation, the fibre ribbon was loaded with hydrogen for 20 days at room temperature at a pressure of 150 atmospheres, in order to increase the writing efficiency. The Bragg grating wavelength $\lambda_{B}$ is fixed by the angle $\alpha$ between the laser beam and the mirror and defined by the relation : $\lambda_{\mathrm{B}}=\frac{\mathrm{n}_{\text {eff }}(\lambda) \cdot \lambda_{\mathrm{P}}}{\sin \alpha}$, where $\mathrm{n}_{\mathrm{eff}}(\lambda)$ is the fibre core effective index at $\lambda$. The gratings $(50 \%$ reflectivity, $10 \mathrm{~mm}$ long) were written successively by moving the cylindrical lens by means of a micro-translation stage ( see the set-up, Figure 2).
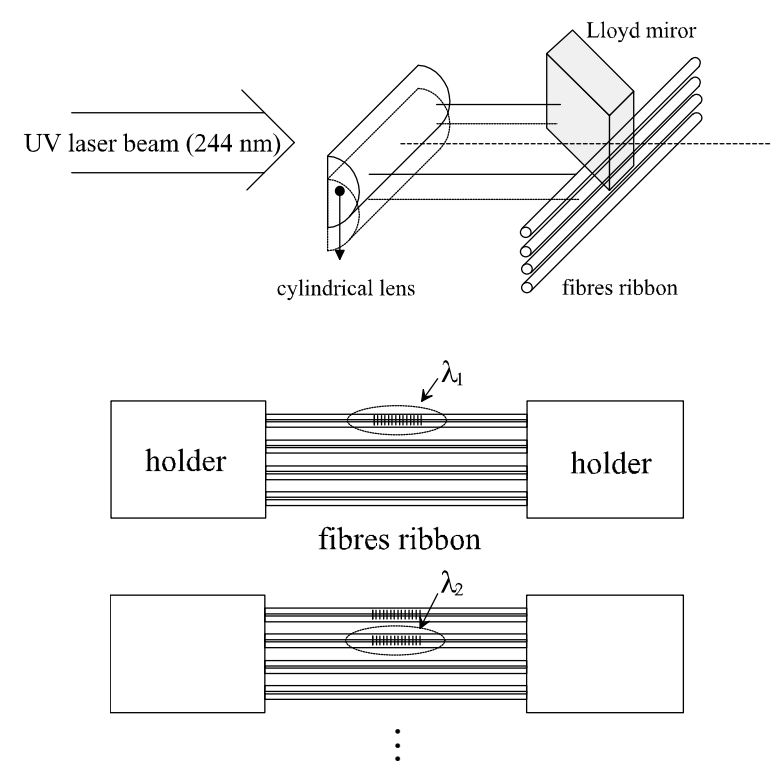

Fig. 2 Bragg gratings writing process.

Secondly micro-optics called GRADISSIMO were made at the end of this fibre ribbon. They are based upon a GRADed Index section, which acts as a graded index (GRIN) lens, aligned and maintained with a coreless Silica section at the appropriate distance from the SIngle MOde fibre (Fig.1). The fabrication process which has been described elsewhere [6] [8] [9] is briefly sketched in Figure 3. It consists in splicing graded index and silica fibre ribbons with an arc-discharge fibre ribbon splicer. Then the coreless silica ribbon is cleaved to obtain a length $\mathrm{L}_{\mathrm{s}}$ of silica.

These silica sections are spliced in ribbon to the SMF ribbon. Finally the GRIN ribbon is cleaved to obtain GRIN sections of the desired length $\mathrm{L}_{\mathrm{g}}$.

The process is collective as only ribbons of GRIN, silica and SingleMode Fibres are clived and spliced.

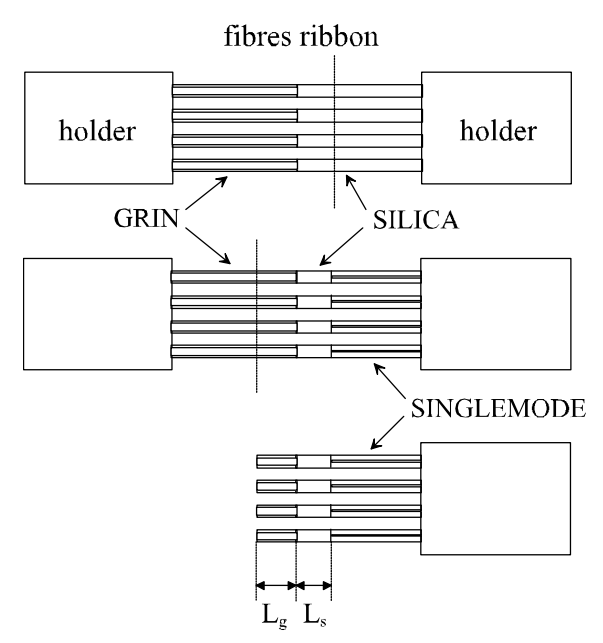

Fig. 3 Micro-optics collective fabrication process.

The $125 \mu \mathrm{m}$ outer diameter is maintained all along the fibres and the pitch between fibres of the ribbon remains $250 \mu \mathrm{m}$. So these ribbons with micro-optics and Bragg reflectors are suitable for hybridisation in $\mathrm{V}$ or $\mathrm{U}$ grooves on silicon motherboards.

The return loss of this micro-optics without any AntiReflection (AR) coating, $>25 \mathrm{~dB}$, is higher than the return loss of a cleaved SMF $(14.7 \mathrm{~dB})$. This relative high return loss associated with a long working distance (around 50 $\mu \mathrm{m})$ are very interesting features to achieve an external cavity source.

\section{Experiments and results}

Each fibre of this non-coated ribbon is then successively aligned in front of a FP/LD operating near $1.3 \mu \mathrm{m}$, whose front facet is AR coated $\left(10^{-4}\right.$ parasitic reflection). So, the $18 \mathrm{~mm}$ long resonant cavity is composed of the non-coated LD back facet and the Bragg reflector (see Fig.1). Light emitting half angles (and radius mode) of $\mathrm{LD}$, at $1 / \mathrm{e}^{2}$ of the maximum intensity, are $25^{\circ}$ 
$(\omega=0.89 \mu \mathrm{m})$ and $30^{\circ}(\omega=0.71 \mu \mathrm{m})$ in the parallel and perpendicular directions against the epitaxial surface, respectively. The different characteristics measured are summarised in Table I.

\begin{tabular}{|l|c|c|c|c|c|c|}
\hline & $\begin{array}{c}\text { Working } \\
\text { distance } \\
(\mu \mathrm{m})\end{array}$ & $\begin{array}{c}\text { Power } \\
(\mathrm{mW})\end{array}$ & $\lambda(\mathrm{nm})$ & $\begin{array}{c}\text { SMSR } \\
(\mathrm{dB})\end{array}$ & $\begin{array}{c}\text { RIN } \\
(\mathrm{dB} / \mathrm{Hz})\end{array}$ & $\begin{array}{c}\text { FWHM } \\
(\mathrm{pm})\end{array}$ \\
\hline Fibre 1 & 46,7 & 3,32 & 1279,97 & 44,1 & $-139,9$ & 76 \\
\hline Fibre 2 & 45,4 & 3,24 & 1282,44 & 46,2 & $-141,7$ & 73 \\
\hline Fibre 3 & 46,5 & 3,04 & 1284,84 & 45 & $-135,8$ & 74 \\
\hline Fibre 4 & 46,6 & 3,08 & 1286,84 & 42,5 & -137 & 74 \\
\hline
\end{tabular}

Table I. Measured results for each fibre in front of the LD.

Due to micro-optics, the working distances between the LD and fibres are homogeneous $(46 \pm 0.7 \mu \mathrm{m})$ and long enough to reduce drastically parasitic reflections on fibres compared with SMF butt coupling. The optical powers are also uniform around $3.18 \pm 0.14 \mathrm{~mW}(4.5 \mathrm{~dB}$ loss compared with $10.5 \mathrm{~dB}$ for butt coupling) for a $60 \mathrm{~mA} \mathrm{LD}$ bias current at $22^{\circ} \mathrm{C}$. Notice that the same micro-optics in front of tapered LD leads to $1.07 \mathrm{~dB}$ loss.

We obtain a single-longitudinal mode emission in each fibre (Figure 4), with a wavelength spacing between two neighbouring channels around $2.3 \mathrm{~nm}(421.1 \mathrm{GHz})$ from 1280 to $1286.81 \mathrm{~nm}$, a Side-Mode-Suppression Ratio (SMSR) of $44.35 \pm 1.85 \mathrm{~dB}$, and a $3 \mathrm{~dB}$ bandwidth (FWHM) of $76 \pm 1.7 \mathrm{pm}(13.7 \mathrm{GHz})$. The Relative Intensity Noise (RIN) [10] is measured between -141.7 and $-135.8 \mathrm{~dB} / \mathrm{Hz}$ for the four fibres. As a comparison we have measured the RIN of a DFB laser diode around -155 $\mathrm{dB} / \mathrm{Hz}$. We could reduce the RIN of the external cavity LD by using a more selective Fibre Bragg Grating.

The measurement precisions are $\pm 2.5 \mu \mathrm{m}$ for the working distance, $\pm 0.1 \mathrm{~mW}$ for the power, $\pm 20 \mathrm{pm}$ for the wavelength, $\pm 0.5 \mathrm{~dB}$ for the SMSR, $\pm 2 \mathrm{~dB} / \mathrm{Hz}$ for the RIN and \pm 3 pm for the bandwith.

The experiment was made around $1300 \mathrm{~nm}$ because componants were available in the laboratory at this wavelength but the same experiment could be reproduced at a wavelength of $1550 \mathrm{~nm}$.

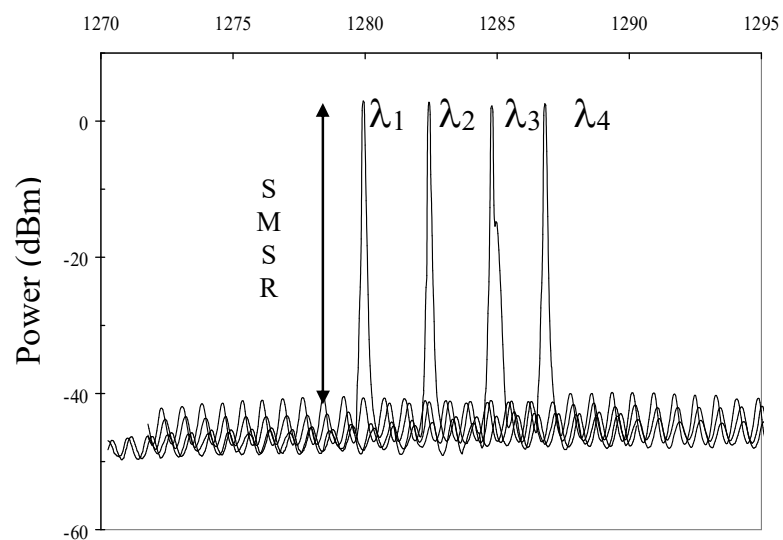

Fig.4 Spectrum in each channel (span $17 \mathrm{~nm})$.

\section{Conclusions}

We have presented four single-longitudinal mode external cavity sources $(\mathrm{SMSR}=44.35 \pm 1.85 \mathrm{~dB}, \mathrm{RIN}$ around $-140 \mathrm{~dB} / \mathrm{Hz}$ ), about $2.3 \mathrm{~nm}$ spaced wavelengths around $1284 \mathrm{~nm}$ and uniform optical powers (3.18 \pm $0.14 \mathrm{~mW}$ ), based on a four channels fibres ribbon. Both grating fabrication process and micro-optics arrangement are performed collectively on this fibre ribbon. This method can be applied successfully to hybridisation on silicon motherboards, which is promising to reduce the assembling cost of multiwavelengths sources for DWDM purposes [11].

\section{Acknowledgments}

The authors would like to thank J.F. Bayon for loading ribbon with hydrogen before UV-writing, J. Landreau for anti-reflection coating, N. Devoldere, A. Le Corre, M. Gadonna and D. Pavy for fruitful discussions. 


\section{References}

[1] F. Le Gall, S. Mottet, N. Devoldère, J. Landreau, 24th European Conference on Optical Communications, ECOC'98, Madrid, 285-286, September (1998).

[2] V. Mizrahi, Technical digest OFC/IOOC'93, number FA8, 243-244 (1993).

[3] C. R. Giles, Journal of Lightwave Technology, 15, (8), 1391-1404 (1997).

[4] J. F. Lemieux, A. Bellemare, C. Latrasse and M. Têtu, Electron. Lett., 35, (11), (1999).

[5] C.A. Armiento, M. Tabasky, C. Jagannath, T. W. Fitzerald, C. L. Shieh, V. Barry, M. Rothman, A. Negry, P. O. Haugsjaa and H. F. Lockwood, Electron. Lett., 27, (12), 1109-1110 (1991).

[6] P. Chanclou, M. Thual, J. Lostec, P. Auvray, J. Caulet, G. Joulie, A. Poudoulec, and B. Clavel, Electron. Lett., 34, (3), 273-274 (1998).

[7] H. Poignant, J. F. Bayon, J. Le Mellot, D. Grot, E. Delevaque, M. Monerie, European Workshop on Bragg Grating Reliability, Berne, CW7, 139-175, October (1995).

[8] P. Chanclou, M. Thual, J. Lostec, D. Pavy, M. Gadonna, A. Poudoulec, Journal of Lightwave Optical Technology, 17, (5), 924-928, (1999).

[9] M. Thual, J. Lostec, P. Auvray and B. Clavel, European Patent EP0825464A1.

[10] I. Joindot, J. Phys III, France 2, 1591-1603, September (1992).

[11] W. Hunziker, Circuits and Devices, 19-25, January (1997). 